\title{
The Competitive Effect In Shift Share Analysis: A Will Of The Wisp? $\uparrow$
}

\author{
Tim C. Ireland and Ronald L. Moomaw*
}

\section{INTRODUCTION}

Although shift-share analysis is the subject of scathing criticisms (e.g., Brown, 1969; Houston, 1967) summarized usefully by Richardson (1978), it continues to be the standardization technique of choice for important analyses of regional and urban growth and development (e.g., Dunn, 1980; Danson, Lever, and Malcolm, 1980). Ashby (1968) and Fothergill and Gudgin (1979) have developed point-by-point refutations of many of the charges levied by the critics of shift-share. Nevertheless, the utility of shift-share analysis depends ultimately upon the extent to which the components of change identified by the standardization correspond to meaningful economic concepts.

The essence of the technique is to decompose some measure of economic activity, say employment or output, in a region into a national growth component, an industry mix component, and a differential component. The national growth component gives the employment or output change that would occur in a region if employment or output in each industry grew at the national average growth rate. ${ }^{1}$ The industry mix component:

... measures the amount of change which can be ascribed to the particular mix of industries in the region. The main point of the technique is to make this measurement. The differential component is merely a residual. Although this residual may reflect the action of many different factors, an examination of its pattern across regions or over time is a potentially very useful guide to the nature of these factors. This is because the removal of one important variable, i.e., industrial composition, leaves a pattern largely caused by the remaining variables (Fothergill and Gudgin, 1979, p. 310$)$.

\footnotetext{
$\dagger$ The authors are particularly indebted to an anonymous referee who induced them to rethink and rewrite the conceptual formulation of the test developed here.

*Assistant Professor of Management Science and Associate Professor of Economics at Oklahoma State University, respectively.
} 
Brown (1969, p. 16), however, argues that the differential or "competitive component is much too broad. The value of the component cannot be clearly interpreted. The economic behavior underlying different values of the competitive component is not distinguishable." Moreover, the "competitive component is supposed to reflect certain economic forces that determine the relative position of various regions with respect to the production of particular goods" (Brown, 1969, p. 10). Brown's position is that the competitive component does not reflect these underlying economic forces. He shows that a projection model based on shift-share analysis does not project as well as simple, alternative models. Furthermore, a reason for this is that the competitive component is unstable over time. Finally, and associated with the instability, he finds that in regression analyses the competitive component is not functionally related to variables that measure competitive advantage.

Brown's work has been used to define the empirical issues regarding the meaning of the competitive component. Paraskevopoulos (1971) and Floyd and Sirmans (1973) in contrast to Brown find that the competitive component is stable over time. Brown (1971; 1973) counters that the former study, which tests the stability of the competitive component for the region rather than for each industry in the region, is irrelevant to his study because it addresses a different question; he argues that the authors of the latter study overstate the case for stability.

Examining shift-share as a predictive tool, Floyd and Sirmans (1973) and James and Hughes (1973), again unlike Brown, find that shift-share projection models perform somewhat better than simple, alternative models. Brown (1973) is not convinced, at least by the former paper.

Finally, Chalmers and Beckhelm.(1976) and Andrikopoulos (1977) have used regression analysis to test whether such determinants of regional advantage as agglomeration economies, wages, and capital formation can explain the competitive component. Unlike Brown, they find that the component is well explained by such variables as these.

Although the conclusion that can be drawn from these examinations of the competitive component is mixed, the competitive component is used to analyze hypotheses about regional change. Rees (1979), for instance, examines the competitive component to test important hypotheses about the role of high-technology firms and industries in the growth of the Sunbelt. Presumably, the validity of his approach is contingent to some extent upon whether the competitive component accurately reflects underlying economic forces.

This study takes a new approach to the examination of the competitive component. It is based on the proposition that a region's competitive advantage in an industry is one determinant of industry investment in the region. If a region's competitive advantage increases, private decisionmakers can be expected to increase investment in the region. Thus, if the competitive component reflects the underlying economic forces that determine competitive advantage, then the competitive component should be positively associated with investment. The study tests this hypothesis for manufacturing industries in one particular state, Oklahoma, which has a 
relatively small but rapidly growing manufacturing sector. This examination allows a test of the competitive component in an environment of a growing manufacturing sector in which investment is important.

In Section II an investment equation is developed with the competitive effect as one explanatory variable. In Section III, estimates of the equation are reported for industries in Oklahoma classified at the two-digit level according to the Standard Industrial Classification (SIC) system. ${ }^{2}$ The results for the two-digit industries indicate that the competitive component is a reasonable proxy for the competitive advantage of a region. The variable is significantly positive in 6 of 12 industries. Furthermore, equations that include the competitive component predict better than an alternative model in 8 or 9 of the 12 industries, depending upon the test statistic examined.

\section{THE INVESTMENT EQUATION AND SHIFT-SHARE ANALYSIS}

The development of the investment equation is based on the twin propositions that investment in a particular industry in a region is positively influenced by the region's competitive advantage and by the industry's national prospects (see Browne, Mieszkowski, and Syron, 1980; and Hodge, 1981). The equation is designed to include the competitive component from a shift-share analysis of real value-added changes as an independent variable. If the competitive component is a proxy for the competitive advantage of a region, then it will be positively associated with investment in the region. ${ }^{3}$

Since investment in the region is expected to be greater the more favorable are the national conditions for the industry, a variable reflecting national conditions should be included. The national growth rate of real output for an industry, therefore, was used to proxy national conditions. Furthermore, since the model is estimated with gross investment data, it is necessary to control for replacement investment. To do so, output in the previous year was included in the equation as a proxy for the amount of capital to be depreciated and hence the amount of investment required for replacement.

The particular measure of the competitive component used in the investment equation was defined by Bishop and Simpson (1972) and by Esteban-Marquillas (1972). ${ }^{4}$ This variable is the difference between the regional and national growth rates for the industry multipled by homothetic output. ${ }^{5}$ Therefore, the competitive effect, by the nature of its construction, is a lagged variable in relationship to current period investment since it involves national and regional output levels from the previous period.

Thus, the investment equation is:

$$
\mathrm{I}_{\mathrm{i}}=\mathrm{a}+\mathrm{b} \mathrm{Ql}_{\mathrm{i}}+\mathrm{c} \mathrm{RN}_{\mathrm{i}}+\mathrm{d} \mathrm{COM}_{\mathrm{i}}+\text { Random Term }
$$


where $\mathrm{a}, \mathrm{b}, \mathrm{c}$, and $\mathrm{d}=$ parameters to be estimated,

$$
\begin{aligned}
\mathrm{I}_{\mathrm{i}} & =\text { real investment in industry } \mathrm{i}, \\
\mathrm{Q}_{\mathrm{i}} & =\text { lagged real output (value-added) in industry } \mathrm{i}, \\
\mathrm{RN}_{\mathrm{i}}= & \text { the national growth rate in industry } \mathrm{i} \text {, and } \\
\mathrm{COM}_{\mathrm{i}}= & \text { the competitive effect in industry i from a shift- } \\
& \text { share analysis. }
\end{aligned}
$$

One would expect the signs on coefficients b, c, and d to be positive.

Equation (1) is not an ideal investment equation. The equation is developed to determine if COM is a useful measure of a region's competitive advantage. Clearly, if the economic forces that the independent variables are proxying could be quantified directly, a superior investment equation could be developed. ${ }^{6}$ The equation also is less than ideal because of its rudimentary lag structure. Unfortunately, there are not enough observations to experiment with various lag structures.

In addition to examining the performance of COM in equation (1), it is also of interest to determine if an equation that includes COM performs better than a simpler alternative. The alternative equation that is tested is one which substitutes the industry growth rate in the region, $R_{i}$, for $R N$ and COM. It is:

$$
\mathrm{I}_{\mathrm{i}}=\mathrm{f}+\mathrm{g} \mathrm{Ql}_{\mathrm{i}}+\mathrm{h} \mathrm{R}_{\mathrm{i}}+\text { Random Term }
$$

where $\mathrm{f}, \mathrm{g}$, and $\mathrm{h}=$ parameters to be estimated,

$$
\begin{aligned}
\mathrm{R}_{\mathrm{i}}= & \text { the regional growth rate of industry } \mathrm{i} \text {, and all } \\
& \text { other variables are as previously defined. }
\end{aligned}
$$

Equation (2) assumes that the separation of national and local effects (RN and COM) conveys little useful information. Therefore, it substitutes one variable $(\mathrm{R})$ for the two separate variables. ${ }^{7}$ The objective is to determine if additional information is gained by examining differential regional growth and the national growth rate of the industry separately vis a vis examining the regional growth rate. In the next section, estimates of equations (1) and (2) are reported and compared.

\section{ESTIMATION AND TESTING}

Twelve two-digit manufacturing industries in Oklahoma were chosen as the sample in which to estimate equations (1) and (2). A shift-share analysis was performed on annual value-added data for each industry over the period of 1964-1977. The competitive terms from the shift-share analysis were extracted for each industry and used as the time series for the 
TABLE 1

Regression Equations

\begin{tabular}{|c|c|c|c|c|c|c|c|c|c|}
\hline SIC & Industry & Intercept & Q1 & $\mathrm{COM}$ & $\mathrm{RN}$ & $\mathrm{R}$ & $\mathrm{R}^{2}$ & Sy.x & D.W. \\
\hline \multirow[t]{2}{*}{20} & $\begin{array}{l}\text { Food and Kindred } \\
\text { Products }\end{array}$ & $\begin{array}{l}-.514375 \\
(-.06)\end{array}$ & $\begin{array}{l}.064765^{+} \\
(1.77)\end{array}$ & $\begin{array}{l}.0680805 \\
(1.12)\end{array}$ & $\begin{array}{l}43.5173^{+} \\
(1.48)\end{array}$ & XXX & .3511 & 4.88126 & 2.0811 \\
\hline & & $\begin{array}{l}-.351954 \\
(-.04)\end{array}$ & $\begin{array}{l}.0663304 \dagger \\
(1.88)\end{array}$ & $\mathrm{XXX}$ & $\mathrm{XXX}$ & $\begin{array}{l}29.4136+ \\
(1.68)\end{array}$ & .3382 & 4.70027 & 2.0844 \\
\hline \multirow[t]{2}{*}{23} & $\begin{array}{l}\text { Apparel and Other } \\
\text { Textile Products }\end{array}$ & $\begin{array}{l}.132648 \\
(.35)\end{array}$ & $\begin{array}{l}.015585^{\Delta} \\
(3.50)\end{array}$ & $\begin{array}{l}.0381708^{\Delta} \\
(3.81)\end{array}$ & $\begin{array}{l}8.95528^{\Delta} \\
(3.45)\end{array}$ & $\mathrm{XXX}$ & .7712 & .595428 & 1.6651 \\
\hline & & $\begin{array}{l}.191048 \\
(.43)\end{array}$ & $\begin{array}{l}.016513^{\Delta} \\
(3.17)\end{array}$ & XXX & $\mathrm{XXX}$ & $\begin{array}{l}5.27805^{\Delta} \\
(3.78)\end{array}$ & .6614 & .690604 & 1.7763 \\
\hline \multirow[t]{2}{*}{24} & $\begin{array}{l}\text { Lumber and Wood } \\
\text { Products }\end{array}$ & $\begin{array}{l}.593428 \\
(.27)\end{array}$ & $\begin{array}{l}.131724 \dagger \\
(2.18)\end{array}$ & $\begin{array}{l}.069081 \dagger \\
(2.19)\end{array}$ & $\begin{array}{l}-5.23963 \\
(-.48)\end{array}$ & XXX & .4879 & 3.37154 & 1.7394 \\
\hline & & $\begin{array}{l}-.0330268 \\
(-.02)\end{array}$ & $\begin{array}{l}.14095^{\Delta} \\
(2.47)\end{array}$ & $\mathrm{XXX}$ & $\mathrm{XXX}$ & $\begin{array}{l}4.03004^{\Delta} \\
(2.41)\end{array}$ & .4596 & 3.30227 & 1.8455 \\
\hline \multirow[t]{2}{*}{25} & $\begin{array}{l}\text { Furniture and } \\
\text { Fixtures }\end{array}$ & $\begin{array}{l}-.475936 \\
(-.50)\end{array}$ & $\begin{array}{l}.0847816 \dagger \\
(1.86)\end{array}$ & $\begin{array}{l}.00714382 \\
(.39)\end{array}$ & $\begin{array}{l}.831424 \\
(.22)\end{array}$ & $\mathrm{XXX}$ & .2920 & 1.21559 & 1.7068 \\
\hline & & $\begin{array}{l}-.452138 \\
(-.51)\end{array}$ & $\begin{array}{l}.0846574 \dagger \\
(1.97)\end{array}$ & $\mathrm{XXX}$ & XXX & $\begin{array}{l}.350455 \\
(.37)\end{array}$ & .2894 & 1.15535 & 1.7417 \\
\hline \multirow[t]{2}{*}{27} & $\begin{array}{l}\text { Printing and } \\
\text { Publishing }\end{array}$ & $\begin{array}{l}-9.33648 \\
(-1.50)\end{array}$ & $\begin{array}{l}.145233^{\Delta} \\
(2.82)\end{array}$ & $\begin{array}{l}.117929 \\
(1.25)\end{array}$ & $\begin{array}{l}21.2261 \\
(.83)\end{array}$ & $\mathrm{XXX}$ & .4642 & 4.212 & 1.1609 \\
\hline & & $\begin{array}{l}-9.27631 \\
(-1.58)\end{array}$ & $\begin{array}{l}.145076^{\Delta} \\
(2.95)\end{array}$ & $\mathrm{XXX}$ & $\mathrm{XXX}$ & $\begin{array}{l}21.3971 \\
(1.34)\end{array}$ & .4552 & 4.04975 & 1.2171 \\
\hline \multirow[t]{2}{*}{29} & $\begin{array}{l}\text { Petroleum and Coal } \\
\text { Products }\end{array}$ & $\begin{array}{l}191.656 \\
(2.76)\end{array}$ & $\begin{array}{l}-.0619504 \\
(-1.02)\end{array}$ & $\begin{array}{l}-.201699 \\
(-1.62)\end{array}$ & $\begin{array}{l}-24.7264 \\
(-1.28)\end{array}$ & XXX & .8684 & 8.77127 & $\begin{array}{c}1.5014 \\
\mathrm{p}=.9666^{*}\end{array}$ \\
\hline & & $\begin{array}{l}166.95 \\
(2.99)\end{array}$ & $\begin{array}{l}-.049316 \\
(-1.00)\end{array}$ & $\mathrm{XXX}$ & $\mathrm{XXX}$ & $\begin{array}{l}-18.3668 \\
(-3.68)\end{array}$ & .8734 & 8.16153 & $\begin{array}{c}1.6536 \\
\mathrm{p}=.9620^{*}\end{array}$ \\
\hline
\end{tabular}




\begin{tabular}{|c|c|c|c|c|c|c|c|c|c|}
\hline SIC & Industry & Intercept & Q1 & $\mathrm{COM}$ & $\mathrm{RN}$ & $\mathrm{R}$ & $\mathrm{R}^{2}$ & Sy.x & D.W. \\
\hline \multirow[t]{2}{*}{30} & $\begin{array}{l}\text { Rubber and Plastic } \\
\text { Products }\end{array}$ & $\begin{array}{l}11.8695 \\
(1.85)\end{array}$ & $\begin{array}{l}-.031128 \\
(-.75)\end{array}$ & $\begin{array}{l}.538692^{\Delta} \\
(2.41)\end{array}$ & $\begin{array}{l}62.1808^{+} \\
(1.69)\end{array}$ & XXX & .3925 & 9.5164 & 1.1474 \\
\hline & & $\begin{array}{l}10.7821 \\
(2.41)\end{array}$ & $\begin{array}{l}-.0272665 \\
(-.80)\end{array}$ & $\mathrm{XXX}$ & $\mathrm{XXX}$ & $\begin{array}{l}70.8044^{\Delta} \\
(3.38)\end{array}$ & .5113 & 8.13827 & 1.3668 \\
\hline \multirow[t]{2}{*}{32} & $\begin{array}{l}\text { Stone, Clay and } \\
\text { Glass Products }\end{array}$ & $\begin{array}{l}-26.211 \\
(-1.99)\end{array}$ & $\begin{array}{l}.271748^{\Delta} \\
(3.09)\end{array}$ & $\begin{array}{l}.130979 \\
(.97)\end{array}$ & $\begin{array}{l}26.1148 \\
(.84)\end{array}$ & $\mathrm{XXX}$ & .5373 & 7.20281 & 2.3933 \\
\hline & & $\begin{array}{l}-26.3692 \\
(-2.09)\end{array}$ & $\begin{array}{l}.273549^{\Delta} \\
(3.24)\end{array}$ & XXX & $\mathrm{XXX}$ & $\begin{array}{l}19.2773 \\
(1.36)\end{array}$ & .5310 & 6.91426 & 2.3640 \\
\hline \multirow[t]{2}{*}{34} & $\begin{array}{l}\text { Fabricated Metal } \\
\text { Products }\end{array}$ & $\begin{array}{l}-23.2864 \\
(-1.35)\end{array}$ & $\begin{array}{l}.157266 \dagger \\
(2.13)\end{array}$ & $\begin{array}{l}.0368991^{+} \\
(1.46)\end{array}$ & $\begin{array}{l}34.0449+ \\
(1.75)\end{array}$ & $\mathrm{XXX}$ & .6864 & 4.18685 & $\begin{array}{c}1.5487 \\
\mathrm{p}=.5854^{*}\end{array}$ \\
\hline & & $\begin{array}{l}-9.55621 \\
(-.74)\end{array}$ & $\begin{array}{l}.0991569^{+} \\
(1.79)\end{array}$ & $\mathrm{XXX}$ & XXX & $\begin{array}{l}13.2789+ \\
(1.90)\end{array}$ & .6542 & 4.17069 & $\begin{array}{c}1.4926 \\
\mathrm{p}=.6103^{*}\end{array}$ \\
\hline \multirow[t]{2}{*}{35} & Machinery & $\begin{array}{l}-4.22585 \\
(-1.47)\end{array}$ & $\begin{array}{l}.0701916^{\Delta} \\
(10.93)\end{array}$ & $\begin{array}{l}.044662+ \\
(1.50)\end{array}$ & $\begin{array}{l}63.5063^{\Delta} \\
(4.54)\end{array}$ & $\mathrm{XXX}$ & .8778 & 5.51948 & $\begin{array}{c}2.8817 \\
\mathrm{p}=-.7774^{*}\end{array}$ \\
\hline & & $\begin{array}{l}-3.17678 \\
(-.72)\end{array}$ & $\begin{array}{l}.0697268^{\Delta} \\
(6.90)\end{array}$ & $\mathrm{XXX}$ & $\mathrm{XXX}$ & $\begin{array}{l}31.2205 \dagger \\
(2.15)\end{array}$ & .7359 & 7.69698 & $\begin{array}{c}2.0714 \\
\mathrm{p}=-.5678^{*}\end{array}$ \\
\hline \multirow[t]{2}{*}{36} & $\begin{array}{l}\text { Electrical and } \\
\text { Electronic }\end{array}$ & $\begin{array}{l}2.74219 \\
(.82)\end{array}$ & $\begin{array}{l}.0430734 \dagger \\
(2.18)\end{array}$ & $\begin{array}{l}.00475639 \\
(.24)\end{array}$ & $\begin{array}{l}6.9473 \\
(.62)\end{array}$ & $\mathrm{XXX}$ & .3291 & 3.71125 & 1.8872 \\
\hline & & $\begin{array}{l}3.1966 \\
(1.07)\end{array}$ & $\begin{array}{l}.0410346^{\Delta} \\
(2.21)\end{array}$ & $\mathrm{XXX}$ & $\mathrm{XXX}$ & $\begin{array}{l}3.73141 \\
(.69)\end{array}$ & .3312 & 3.53304 & 2.1310 \\
\hline \multirow[t]{2}{*}{37} & $\begin{array}{l}\text { Transportation } \\
\text { Equipment }\end{array}$ & $\begin{array}{l}-9.34531 \\
(-2.59)\end{array}$ & $\begin{array}{l}.0878817^{\Delta} \\
(4.64)\end{array}$ & $\begin{array}{l}.0668645^{\Delta} \\
(6.09)\end{array}$ & $\begin{array}{l}29.1402^{\Delta} \\
(3.88)\end{array}$ & XXX & .7999 & 2.15688 & 2.4843 \\
\hline & & $\begin{array}{l}-11.4791 \\
(-2.79)\end{array}$ & $\begin{array}{l}.100886^{\Delta} \\
(4.60)\end{array}$ & XXX & XXX & $\begin{array}{l}26.5921^{\Delta .} \\
(3.19)\end{array}$ & .7223 & 2.42274 & 2.6688 \\
\hline
\end{tabular}

${ }^{+}$Denotes significance at .10 level.

$\dagger$ Denotes significance at .05 level.

$\Delta$ Denotes significance at .025 level. 
independent variable of interest (COM) in equation (1). These regressions were then performed and compared to the alternative as represented by equation (2). Before examining these regression results, some of the characteristics of the 12 industries in the study are discussed.

The 12 industries of the study include: food and kindred products (SIC 20); apparel and other textile products (SIC 23); lumber and wood products (SIC 24); furniture and fixtures (SIC 25); printing and publishing (SIC 27); petroleum and coal products (SIC 29); rubber and plastic products (SIC 30); stone, clay, and glass products (SIC 32); fabricated metal products (SIC 34); machinery (SIC 35); electrical and electronic equipment (SIC 36); and transportation equipment (SIC 37). These industries were chosen for the analysis because consistent value-added time series existed for at least 14 years. Most of the other two-digit manufacturing industries in the state had severe data gaps.

The 12 manufacturing industries can be partitioned into five nondurables and seven durables. The five nondurables in the study (SIC 20, 23, 27, 29 , and 30) constitute 84.4 percent of the total nondurables value-added from Oklahoma manufacturing in 1977. The seven durables (SIC 24, 25, $32,34,35,36$, and 37 ) that are in the sample produced 90.4 percent of the durables total in 1977. Altogether, the 12 industries provided 87.9 percent of total manufacturing value-added in Oklahoma for 1977.

The data used in the estimates of equations (1) and (2) were taken from the Annual Survey of Manufacturers. Ordinary least squares regressions were performed on each of the 12 manufacturing industries. Where severe serial correlation was detected, the Cochrane-Orcutt (1949) transformation was made. The resulting equations and their accompanying statistics are presented in Table 1.

The first issue to be dealt with in the analysis is the question of whether the competitive term is a relevant measure of competitive advantage in a region and, therefore, can explain investment activity. If the term is a good measure then we would expect the sign on the variable in the regression equations to be significantly positive. The competitive coefficient is positive in all but one case, petroleum and coal products (SIC 29), but t-tests are needed to determine the significance of these coefficients.

One-tailed t-tests were performed at three different levels of significance $(.025, .05$, and .10$)$ to test the hypothesis that the competitive term's

TABLE 2.

Significance of Selected Regression Coefficients

\begin{tabular}{cccc}
\hline & \multicolumn{3}{c}{ Significantly Positive } \\
1-Tailed Significance & COM & RN & $\mathrm{R}$ \\
\hline$\alpha=.025$ & 3 & 3 & 4 \\
$\alpha=.05$ & 4 & 3 & 6 \\
$\alpha=.10$ & 6 & 6 & 7 \\
\hline
\end{tabular}


coefficient was greater than zero. Table 2 summarizes these results. At the strictest significance level $(\alpha=.025)$, the competitive coefficient was significantly positive in 3 of 12 cases. The term was significant in 4 industries at the .05 level of significance while significance was achieved in half of the cases (6 of 12) at the .10 significance level.

The coefficient of the national growth rate was also significantly positive in 6 industries at the .10 level. Three of these coefficients were significant at the .025 level, just as with the competitive variable. For 5 industries, both the competitive effect and the national growth rate were significant and separate influences on state investment. The competitive effect was significant in an additional industry, as was the national growth rate. Relatively high simple correlations between the two variables may explain the failure of the variables to achieve significance in the equations. Or, the industries may need further disaggregation.

In his study of four industries using a sophisticated investment equation, Hodge (1981) obtained results that were similar. In one industry both local and national variables performed as expected. In another, none of the local variables were significant. The remaining two industries yielded mixed results on the local variables.

In the alternative equation (equation 2) with the regional growth rate for the industry substituted for the national growth rate and the competitive effect, the regional growth rate is significantly positive in 7 of the 12 industries (see Table 2). Thus, this variable performs somewhat better than the two variables that it replaces in terms of significance levels. On an industry basis, however, the competitive component and/or the national growth rate also were significant in 7 industries. ${ }^{8}$

TABLE 3.

Simulation Error Statistics

\begin{tabular}{ccccc}
\hline & \multicolumn{2}{c}{ Theil U } & \multicolumn{2}{c}{ MAPE } \\
\hline & $\begin{array}{c}\text { COM } \\
\text { Model } \\
\text { (Eq. 1) }\end{array}$ & $\begin{array}{c}\text { Naive } \\
\text { Model } \\
\text { Industry }\end{array}$ & $\begin{array}{c}\text { COM } \\
\text { Model }\end{array}$ & $\begin{array}{c}\text { Naive } \\
\text { Model } \\
\text { (Eq. 2) }\end{array}$ \\
20 & .1280 & .1293 & 23.86 & 23.21 \\
23 & .1162 & .1422 & 30.55 & 37.17 \\
24 & .2398 & .2472 & 102.39 & 119.71 \\
25 & .3433 & .3441 & 100.33 & 101.20 \\
27 & .1946 & .1964 & 34.35 & 33.65 \\
29 & .2064 & .1980 & 80.92 & 74.54 \\
30 & .2204 & .1958 & 68.64 & 55.99 \\
32 & .1771 & .1784 & 29.90 & 29.97 \\
34 & .1592 & .1753 & 43.38 & 44.05 \\
35 & .1272 & .1520 & 20.32 & 28.06 \\
36 & .1531 & .1529 & 28.82 & 29.31 \\
37 & .1010 & .1194 & 20.21 & 26.59 \\
Average & .1805 & .1859 & 48.64 & 50.29 \\
\hline
\end{tabular}


Although the competitive component has a significantly positive influence on investment in some industries, the regional growth rate variable in equation (2), which does not separate local and national variables, also performs well. The question remains of whether an equation with the competitive effect (equation 1) can explain investment behavior better than an equation which substitutes the industry growth rate in the region (equation 2). To make this comparison, the estimated regression equations were simulated over the 1964-1977 sample period. Two error statistics, the Theil U-statistic and the mean absolute percentage error (MAPE), were computed for each industry. ${ }^{9}$ The results of those tests are presented in Table 3.

The error structures presented by both the Theil U-statistic (inequality coefficient) and the MAPE statistic are fairly consistent. The better model is denoted, of course, by the form which produces the lower error statistic. Using the Theil statistic, head to head comparisons of the two equation forms for each industry showed the competitive form recording lower errors in 9 of 12 industries. For the MAPE statistic, the equations involving the competitive term from the shift-share analysis produced lower errors in 8 of 12 manufacturing industries.

Averages across all industries for a particular error statistic and model form were also computed. The competitive form of the model (equation 1) recorded lower average errors for both the Theil U-statistic and the MAPE statistic. Using the Theil criterion, the competitive form listed an average U-statistic of .1805 while the naive form (equation 2) reported an average U-statistic of .1859. The MAPE statistic showed average errors of 48.64 and 50.29 for the competitive and naive forms, respectively.

\section{RESULTS AND CONCLUSIONS}

This study provides a simple, new way of testing the economic meaningfulness of the competitive component from a shift-share analysis. Controversy has long surrounded the question of whether the competitive component accurately reflects underlying economic forces. Our approach is based on the notion that if the competitive effect reflects a region's competitive advantage in a particular industry, then it should partially explain the investment activity in that industry. Specifically, investment behavior in an industry should be positively related to the competitive effect from a shift-share analysis of the industry.

Twelve two-digit manufacturing industries from the State of Oklahoma were used to test the proposed hypothesis. These industries were selected due to the completeness of their data series, but they did constitute the bulk of manufacturing activity in the state. For comparative purposes, an alternative equation was also estimated for each industry. This alternative replaced the competitive effect and the national growth rate of the industry with the regional growth rate of the industry as an explanatory variable.

Ordinary least squares regressions were performed for each industry with Cochrane-Orcutt transformations where deemed necessary. Statisti- 
cal significance tests showed that in 6 of 12 manufacturing industries the competitive component was significantly positive at the .10 significance level. These results, although not conclusive, suggest that the competitive effect does, to use Brown's phrase, “. . . reflect certain economic forces that determine the relative position of various regions ..."

Simulations were performed over the estimation period and two error measures, the Theil U-statistic and the mean absolute percentage error (MAPE), were computed. These simulations were made to compare the predictive power of the competitive component equation with that of a simple, naive alternative. These tests showed that in over two-thirds of the industries the regression equations involving the competitive component produced lower simulation error statistics. This result suggests that a separate examination of the competitive component and the national growth rate of an industry provides more information about the determinants of investment than does an examination of only the regional growth rate.

This study has shown that the competitive effect may be a proxy for the relative advantage that a region has for various industries. If the results of this study were to be confirmed for other states or regions, which might have sufficiently available data to experiment with somewhat more elaborate equations, the competitive component would be shown conclusively to be more than just ". . . a random variable" (Brown, 1969, p. 15).

\section{FOOTNOTES}

\begin{abstract}
${ }^{1}$ As Bishop and Simpson (1971) demonstrate, at least three meaningful decompositions of employment change can be constructed. Since this study concentrates on the differential component, which is the same in all three approaches, it is sufficient to examine only one technique.

${ }^{2}$ Determining the level of industrial detail that approximates a well-defined industry is a problem that plagues shift-share analysis. Using two-digit detail in a crosssectional study might result in inappropriate cross state comparisons of a particular industry. This would be so if the same two-digit "industry" had vastly different industry composition at the three-digit level of detail in different states. This study, however, uses a short time and a single state; in such a series one would not expect the industry composition to vary as much. Thus, the aggregation may not be as severe in this study. Problems do remain, of course, in comparing the growth rate of the two-digit state industry to the growth of the corresponding two-digit national industry.

${ }^{3}$ The empirical test is based on the proposition that the decision to invest in a particular region depends upon the decision-maker's perception of the competitive advantages of the region, other things equal. Thus, it is assumed to be true that:
\end{abstract}

(a) Investment $=\mathrm{f}($ competitive advantage,$\ldots)$. The hypothesis to be tested is that:

(b) Investment $=\mathrm{g}$ (competitive component of the shift-share analysis, ...).
Using appropriate statistical significance tests, if (a) is true, and the sign of the competitive component in (b) is found to be negative or zero, it can be concluded that the competitive component does not reflect competitive advantage. Alternatively, if the sign in (b) is found to be positive, the result is consistent with the proposition that the competitive component is a proxy for competitive advantage.

${ }^{4}$ The pros and cons of using this measurement of the competitive effect have appeared in the literature (Stokes, 1974; Herzog and Olsen, 1977, 1979; and Beaudry and Martin, 1979).

${ }^{5}$ Homothetic output is the output that the industry would have in the region if the region and nation had the same proportion of their total output in each industry.

${ }^{6}$ Hodge (1981) develops estimates of an equation that uses rational expectation concepts to model investment decision-making and the allocation of investment over regions. Browne, Mieszkowski, and Syron (1980) also develop and estimate an investment equation. Both studies incorporate national and local variables into the analysis. In our equation, $\mathrm{RN}$ can be taken as a proxy for national variables and COM as a proxy for local variables.

${ }^{7}$ The simpler, alternative model denoted by equation (2) is similar to the "regional rate" model used by Floyd and Sirmans (1973) as a comparison model for shiftshare projections.

${ }^{8}$ Two additional observations about the estimates are of interest. First, QD1, output lagged, is significantly positive for both specifications in 10 of the 12 industries. 
Second, for industry 29 the coefficients of all variables are negative and some of them significantly so. The poor results for this industry, petroleum refining, are probably related to the price controls on crude petroleum and the general energy situation of the 1970s.

${ }^{9}$ It is desirable to undertake ex post forecasting tests as well as ex post simulation measurements. However, data inavailabilities and the need to have a sufficient number of degrees of freedom in the estimation process prevented having out-of-the-sample observations to make these tests. These ex post forecasting tests can be made as new observations become available.

\section{REFERENCES}

Ashby, L. D. "The Shift and Share Analysis: A Reply," Southern Economic Journal, 34 (1968):423-25.

Andrikopoulos, A. A. "Regional Growth Differential in Manufacturing Employment: The Case of the Province of Ontario, Canada," The Review of Regional Studies, 7 (1977):45-61.

Beaudry, R. and Martin F. "Shift-Share Analysis Revisited: The Allocation Effect and the Stability of Regional Structure, a Comment," Journal of Regional Science, 19 (1979):389-391.

Bishop, K. C. and Simpson, C. E. "Components of Change Analysis: Problems of Alternative Approaches to Industrial Structure," Regional Studies, 6 (1972):59-68.

Brown, H. J. "Shift and Share Projections and Regional Economic Growth: An Empirical Test," Journal of Regional Science, 9 (1969): 1-18

Brown, H. J. "The Stability of the Regional Share Component: Reply," Journal of Regional Science, 11 (1971):113-114.

Brown, H. J. "Shift and Share Projections Revisited: A Reply," Journal of Regional Science, 13(1973):121.

Browne, L., Mieszkowski, P. and Syron, R. "Regional Investment Patterns," New England Economic Review, (July-August 1980):5-23

Chalmers, J. A. and Beckhelm, T. L. "Shift and Share and the Theory of Industrial Location," Regional Studies, 10 (1976):15-23.

Danson, M. W., Lever, W. F., and Malcolm, J. F. "The Inner City Employment Problem in Great Britain 1952-1976: A Shift-Share Approach," Urban Studies, 17 (1980):193-210

Dunn, E. S., Jr. The Development of the U.S. Urban System: Concepts, Structures Regional Shifts, Vol. I. Baltimore: Johns Hopkins University Press, 1980.

Esteban-Marquillas, J. M. "A Reinterpretation of ShiftShare Analysis," Regional and Urban Economics 2, 3 (1972):249-261.
Floyd, C. F. and Sirmans, C. F. "Shift and Share Projections Revisited," Journal of Regional Science, 13 (1973):115-120.

Fothergill, S. and Gudgin, G. "In Defense of ShiftShare," Urban Studies, 16 (1979):303-319.

Herzog, H. W., Jr. and Olsen, R. J. "Shift-Share Analysis Revisited: The Allocation Effect and the Stability of Regional Structure," Journal of Regional Science, 17 (1977):441-454.

Herzog, H. W., Jr. and Olsen, R. J. "Shift-Share Analysis Revisited: The Allocation Effect and the Stability of Regional Structure, a Reply. Journal of Regional Science, 19 (1979):393-395.

Hodge, J. H. "A Study of Regional Investment Decisions," Research in Urban Economics, V. 1., ed. J. V. Henderson. Greenwich, Conn.: JAI Press, Inc., 1981. pp. 1-66.

Houston, D. "Shift and Share Analysis: A Critique," Southern Economic Journal, 33 (1967)577-581.

James, F., Jr. and Hughes, J. "A test of Shift and Share Analysis as a Predictive Device," Journal of Regional Science, 13 (1973):223-231.

Paraskevopoulos, C. C. "The Stability of the RegionalShare Component: An Empirical Test," Jourmal of Regional Science, 11 (1971):107-112.

Pindyck, R. S. and Rubinfeld, D. L. Econometric Models and Economic Forecasts. New York: McGraw-Hill, 1976.

Rees, J. "Regional Industrial Shifts in the U.S. and the Internal Generation of Manufacturing in Growth Centers of the Southwest," Interregional Movements and Regional Growth, ed. W. C. Wheaton, Washington: The Urban Institute, 1979. pp. 51-74.

Richardson, H. W. Urban and Regional Economics. Hamondworth: Penguin, 1978.

Stokes, H. K., Jr. "Shift-Share Once Again," Regional and Urban Economics, 4 (1974):57-60.

Theil, H. Applied Economic Forecasting. Chicago: Rand McNally and Co, 1966. 